\title{
VIRTUALITY AS A PRECONDITION AND NECESSITY FOR THE MANKIND DEVELOPMENT
}

\author{
VIRTUALIDADE COMO PRECONDIÇÃO E NECESSIDADE \\ PARA O DESENVOLVIMENTO HUMANO \\ LA VIRTUALIDAD COMO PRECONDICIÓN Y NECESIDAD \\ PARA EL DESARROLLO HUMANO
}

Ihor Hurnyak ${ }^{1}$

Aleksandra Kordonska ${ }^{2}$

\section{Cite as - American Psychological Association (APA)}

Hurnyak, I., \& Kordonska, A. (2020, Sept./Dec.). Virtuality as a precondition and necessity for the mankind development. International Journal of Innovation - IJI, São Paulo, 8(3), 373-391.

https://doi.org/10.5585/iji.v8i3.16010.

\begin{abstract}
Objective of the study: The research aims at exploring the way of interaction between virtual and physical reality and defining the approaches to analyze consequences of the virtuality penetration to the real world or vice versa.

Methodology / approach: We apply a game theoretic method based on payoff matrix to show the essence of interaction between virtual and physical worlds; an internalization approach for solving optimization problem; graphical visualization of the interaction by using cones movement approach and analysis of cost functions to develop an equation of the city's economy and to rebuild a model of optimal city size.

Originality / Relevance: The majority of economic approaches have a linear-minded nature and only some take into account technological aspect. We state that the solution lies in consideration the costs as function of positive and negative exponential externalities. The proposed cost-based approach allows finding the optimal distribution of the time staying in the virtual and physical space.

Main results: Obtained results of the research proved the following assumptions: interaction with new reality has changed us; a human is irrational in absolute majority; virtuality is a threat and an opportunity to the human. We confirmed that the nature of interaction between physical and virtual reality should takes the form of cooperation to ensure the mankind development.

Theoretical / methodological contributions: It is one of the first attempts to develop economic theories and methods by extending them with variables of virtual reality.

Social / management contributions: The study presents a broader view on human who exists on the fringes of physical and virtual reality.
\end{abstract}

Keywords: Virtuality. Irrational nature of human. Nash equilibrium. Interaction. Positive externality. Negative externality.

${ }^{1}$ Universidade Nacional Ivan Franco de Lviv - UNIFL, Lviv - Ucrânia. ag.kpl.lviv@ gmail.com
${ }^{2}$ Universidade de Warmia e Mazury em Olsztyn - UWMO, Olsztyn - Polônia. alexandra.kordonska@gmail.com 


\section{Resumo}

Objetivo do estudo: Esta pesquisa tem como objetivo explorar a forma de interação entre a realidade virtual e realidade física, bem como definir abordagens de análise às consequências da penetração do mundo virtual no mundo real, ou vice-versa.

Metodologia / abordagem: Foi aplicada uma metodologia assente na teoria de jogos, baseada numa matriz de payoff, tendo em vista mostrar a essência da interação entre o mundo virtual e o físico; uma abordagem de internalização para resolver o problema de otimização; visualização gráfica da interação usando abordagem de movimento de cones e análise de funções de custo, com o propósito de desenvolver uma equação representativa economia da cidade e reconstruir um modelo para o seu tamanho ideal.

Originalidade / Relevância: A maioria das abordagens económicas tem uma natureza linear e apenas algumas levam em consideração os aspetos tecnológicos. Neste estudo assumimos que a solução reside na consideração dos custos em função das externalidades exponenciais positivas e negativas. A abordagem proposta, baseada em custos, permite encontrar a distribuição ideal de tempo da permanência no espaço virtual e físico.

Principais resultados: Os resultados obtidos comprovaram os seguintes pressupostos: a interação com a nova realidade mudou-nos; um humano é irracional em maioria absoluta; a virtualidade é uma ameaça e uma oportunidade para o ser humano. Confirmámos que a natureza da interação entre realidade física e virtual deve assumir a forma de cooperação para garantir o desenvolvimento da humanidade.

Contribuições teóricas / metodológicas: É uma das primeiras tentativas de desenvolver teorias e métodos económicos, estendendo-os com variáveis representativas da realidade virtual.

Contribuições sociais / de gestão: O estudo apresenta uma visão mais ampla sobre o ser humano que vive nas franjas da realidade física e virtual.

Palavras-chave: Virtualidade. Natureza irracional do ser humano. Equilíbrio de Nash. Interação. Externalidade positiva. Exterioridade negativa.

\section{Resumen}

Objetivo del estudio: Esta investigación tiene como objetivo explorar la forma de interacción entre la realidad virtual y la realidad física, así como definir los enfoques de análisis de las consecuencias de la penetración del mundo virtual en el mundo real, o viceversa.

Metodología / enfoque: Se aplicó una metodología basada en la teoría de juegos, mediante una matriz payoff, con el fin de mostrar la esencia de la interacción entre el mundo virtual y el físico; un enfoque de internalización para resolver el problema de optimización; visualización gráfica de la interacción utilizando el enfoque de movimiento de cono y análisis de función de costo, con el propósito de desarrollar una ecuación representativa para la economía de la ciudad y reconstruir un modelo a su tamaño ideal.

Originalidad / Relevancia: La mayoría de los enfoques económicos son de naturaleza lineal y solo unos pocos tienen en cuenta los aspectos tecnológicos. En este estudio asumimos que la solución está en la consideración de costos por externalidades exponenciales positivas y negativas. El enfoque propuesto, basado en costos, permite encontrar la distribución ideal del tiempo en el espacio virtual y físico.

Resultados principales: Los resultados obtenidos evidenciaron los siguientes supuestos: la interacción con la nueva realidad nos ha cambiado; un humano es irracional en una mayoría absoluta; la virtualidad es una amenaza y una oportunidad para los seres humanos. Confirmamos que la naturaleza de la interacción entre la realidad física y virtual debe tomar la forma de cooperación para garantizar el desarrollo de la humanidad. 
Contribuciones teóricas / metodológicas: Es uno de los primeros intentos de desarrollar teorías y métodos económicos, ampliándolos con variables representativas de la realidad virtual.

Contribuciones sociales / de gestión: El estudio presenta una visión más amplia del ser humano que vive en la periferia de la realidad física y virtual.

Palabras-clave: Virtualidad. Naturaleza irracional del ser humano. Equilibrio de Nash. Interacción. Externalidad positiva. Exterioridad negativa.

\section{Introduction}

Current short- and long-term changes taking place in the world as a result of accelerated technological development during the last century on the one hand, and outbreak of Coronavirus pandemic in December 2019 on another - have led to a significant modification of the perceiving the nature of reality with which we have dealt so far.

Even in 1965 Gordon E. Moore, former director at Fairchild Semiconductor and cofounder of Intel Corporation forecasted that density of components for information technologies would continue to double every two years, the speed and capability of our computers will increase and so the price will go down and this fact will have a great impact on different industries in general. This prediction was called "Moore's Law" (Schaller, 1997).

According to the Björn Blissing (2016), nowadays we exist in some combination of real and virtual world. The term virtual reality (VR) is used traditionally to describe technology that replaces sensory inputs with artificial ones to make the user believe that he is a part of artificial world. No strict definition of VR exists, but three components are generally described: presence of an interactive computer's simulation, use of a display technique that immerses the user and a view that it is oriented to the user. The field between the completely virtual and the completely real is denoted as mixed reality (MR). When virtual objects are added to the real world, mainly is used the term "augmented reality" (AR). A typical example of AR is to add annotations to objects in the real world, but it can also be to add a virtual object to the real world, such as a virtual teapot placed on a real table or a virtual vehicle in a real traffic environment or a virtual singer from the past on a stage that stands next to a modern star (Blissing, 2016). On this continuum is also (more uncommon) augmented virtuality (AV), which means to add real objects to an otherwise virtual world. Here the interesting issue can arise, what about the human consciousness placed in the world of virtual reality? At least from the medical point of view, such a technological decision can have a significant value. 
According to the Google Books Ngram Viewer ${ }^{3}$ (Figure 1), physical reality has been studied since the emergence of analytical thinking, while the increase of investigations related to virtual reality / virtual world has started since 1990s with the development of proper technologies. So, the problem of virtual reality is relevant but still not thoroughly studied among scientists.

Figure 1 - Search frequencies (\%) for the term "virtual reality," "virtual world" and "physical reality" in sources printed between 1980 and 2019

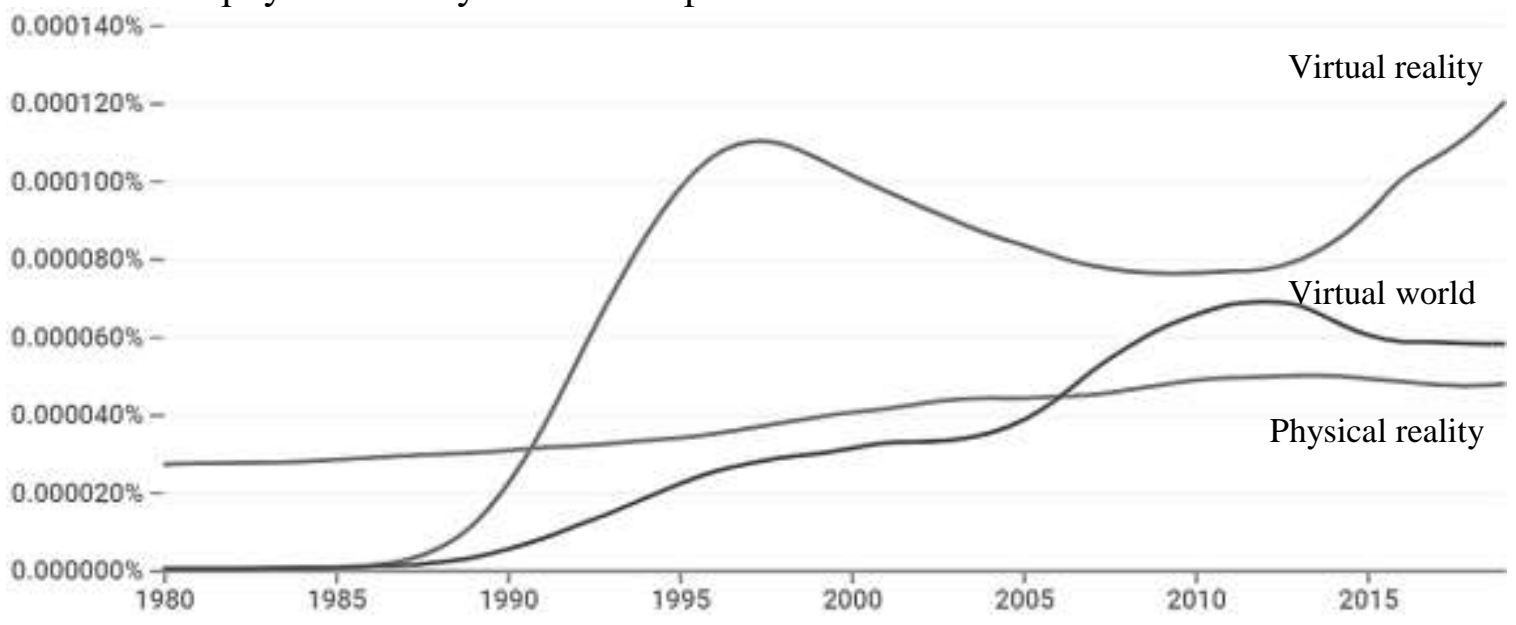

Source: Adapted from Google Books Ngram Viewer.

Referring to Bernard Marr (2019) we can point out the 5 key trends for 2019:

1. AR and VR increasingly enhanced with artificial intelligence (AI).

2. VR and AR will increasingly be used in training and teaching.

3. Consumer Entertainment VR hits the mainstream.

4. VR and AR environments becoming increasingly collaborative and social.

5. AR increasingly finding its way into vehicles.

Therefore, taking into account the relevance of the problem, we would like to focus on interaction of the virtual and physical reality. The purpose of research is to show the way of interaction between virtual and physical reality and approaches to analyze the consequences of the virtuality penetration to the real world or vice versa.

The rest of the paper is structured as follows. Firstly, we show views and predictions of scientists regarding research topic. In the next part (Philosophical approach to the research) we

\footnotetext{
${ }^{3}$ The Google Ngram Viewer or Google Books Ngram Viewer is an online search engine that charts the frequencies of any set of search strings using a yearly count of n-grams found in sources printed between 1500 and 2019 in Google's text corpora in English, Chinese (simplified), French, German, Hebrew, Italian, Russian, or Spanish.
} 
try to understand the essence of the phenomenon in current times by discussing a range of assumptions: (1) Interaction with new reality has changed us. (2) Human is irrational in absolute majority. (3) Virtuality is a threat and an opportunity to the human. Then, we make an attempt to analyze the interaction between physical and virtual reality and their interpenetration by using game theoretic method based on payoff matrix, an internalization approach for solving optimization problem and by graphical visualization of the phenomenon. Furthermore, considering the cost function as a function of positive and negative externalities, we develop an equation of the city's economy by taking into account variables representing virtual reality and try to rebuild a model of optimal city size. So, the methodological basis for the research is both mathematical and economic analysis methods. The last part of the article contains discussion and conclusions of the research.

\section{Theoretical framework}

Ray Kurzweil predicted in 2003, "by the 2030s, virtual reality will be totally realistic and compelling and we will spend most of our time in virtual environments. We will all become virtual humans" (Kurzweil, 2003). Such escapism is nothing new in human history. We must bear in mind the critics concerning increased influence of TV, overpowering Internet and the usage of smartphone. All of this could potentially reorganize traditional approaches to the human development. A lot of reports are related to the self-imposed social isolation confirming the negative side of such form of withdrawal. Among them we can mention a term "hikikomori" that has been used since 1990s to describe millions of Japanese citizens who withdraw from society and seek extreme degree of isolation and confinement. The next example is infamous World of Warcraft players, who lose themselves in their massive online universe. One of the former Warcraft players, who had played it for 60 hours a week, explained to The Guardian (2011) that "living inside World of Warcraft seemed preferable to the drudgery of everyday life."

According to Jim Blascovich and Jeremy Bailensen, "the Internet and virtual realities easily satisfy such social needs and drives - sometimes [they are] so satisfying that addicted users will withdraw physically from society" (Kim, 2015). What could we oppose to "more highly immersive perceptual and psychological experiences" according to the Blascovich? Will we transform physical life or allow a majority of users of the virtual product actually left the reality? But he says: "Who is to say that a virtual life that is better than one's physical life is a 
bad thing?" If someone is able to fulfill his basic human needs in an immersive virtual world, who is to say that they shouldn't?

These examples raise some questions: The virtual reality becomes a way to avoid real life or to influence positively on the everyday life? Does such playing make us believe that we can recreate or change ourselves in the real life? Is it possible to assume that technologies of the virtual world could contribute to the change of the real life for the better? Are the creators of virtual technologies at least partially interested in this, so the user tries to simultaneously improve his life in both worlds? - Here, we should also mention the use of technologies in medicine, business (Carvalho, Kovaleski, et al., 2018) or knowledge transfer (Pham \& Huynh, 2018) that allows looking at this problem more optimistically. Apart from this, whether there is a need in some frames for player to remind him about the existence of the real world, something like "smoking is harmful to your health" or "the use of medicine without a doctor's prescription can harm you." Considering the evidence leading to establishment of the virtual reality, it is reasonable to assume that games should have pushed the player to positive changes in his real life, otherwise it would not be allowed on the market at all. The lack of legislative regulation concerning this issue is relevant and should be discussed, but in no case it have to be transformed into the immoral simulation of the struggle against children dependence on slot machines, as it is happening, for example, in Ukraine.

According to Zion Market Research (2019), the global market of virtual reality was valued at around $\$ 26.7$ billion in 2018 and is expected to reach approximately $\$ 814.7$ billion by 2025 . Among the major players will be: video games ( $\$ 11.6$ billion), health care ( $\$ 5.1$ billion), engineering ( $\$ 4.7$ billion), video entertainment ( $\$ 3.2$ billion), real estate ( $\$ 2.6$ billion), retail ( $\$ 1.6$ billion), military ( $\$ 1.4$ billion) and education (\$7 million) (Bhalavat, 2018). We can also expect a wide use of such technologies in tourism.

On the other hand, we can assume that a value could be even greater considering current times of worldwide pandemic. Even today, we can observe, that new reality in pandemic leads to the accelerated use of technology in the field of business, education and generally services sector. Each kind of activity, in case it is possible, is tried to be provided in distance form. It creates a necessity of adaptation of certain technologies (i.e. Zoom, Microsoft Teams, Skype etc.) to the human needs. It constitutes an excellent reflection of introduction and development of the virtuality in social practice.

An analysis of the history of technology shows that technological change is exponential, contrary to the common-sense "intuitive linear view" (the law of accelerating 
returns). According to the Kurzweil (2003) and some other modern scientists, our intuition can be presented as a linear regression, but information based technology expands as exponential one. The rate of progress of evolutionary process increases exponentially over time. Consequently, we have a majority of the linear-minded approaches and a minority that correlates with existing information based technologies. Let's assume that this minority is conventionally called a "mathematical minority," while the majority - an "irrational majority." Obviously, the first one will be focused on collaboration with the same rational virtuality, when the second - will try to bring an element of irrationality into this virtuality. In this case, the irrational virtuality could be supposed to transform into some destructive mechanism for mankind, as a result of unpredictability.

Considering social effects that are mainly unpredictable, we should concentrate our attention on the externalities. The Coase theorem states that when transaction costs are low, two parties will be able to bargain and reach an efficient outcome in the presence of an externality. According to the Searle's theory, much of our everyday social reality can be recreated in virtual form (Danaher, 2017). So, it has been already 'virtual' in nature. It doesn't depend on any physical, real world properties or characteristics for its existence. Artificial Intelligence fusing man and machine: prostheses and outhouses intensify physical strength, computers support intellectual performance and artificial intelligence has the potential to expand human consciousness. So, it is a high time to deal with the consequences: Will these techniques change our humanity? What needs to be done to minimize risks? And what opportunities are opened up? (Benedikter 2017).

\section{Philosophical approach to the research}

We would like to focus our attention on a range of assumptions that allow us to look at this problem more deeply.

Assumption no. 1. Interaction with new reality has changed us.

Is there such a complex and unpredictable behavior of a person that it could be difficult to simulate virtually? Is a human exclusively moral or creative? What is a value of the human through the prism of virtuality? If we are incapable of responding to the needs of the real world, how can we hope to respond to the needs of this new form of thinking, this ambitious virtual world? Will the virtuality honor a human as a creator? Can the creator refuse the right to consider himself as such? Maybe it is worth to wait not for the beginning of the communication with the extraterrestrial civilizations, but with the Virtuality? Someone could not recognize that 
it will be no longer its creation and may be incomprehensible and inexplicable. Every day we touch upon more and more questions for which we have no answers. We can assume that interaction with new reality has changed humanity. The cave of a human (recalling for a while prof. Michio Kaku (2008, p. 31)) alone with aspire of entertainment, networks (gossip in different technical forms) and overwhelmed by its own, suddenly got a window into the other world. A human will be forced to become better? Maybe the understanding will come to him that it is inevitably for survival, not to achieve new natural resources, precious and/or technical novelties, but to develop own human personality, its quality.

Assumption no. 2. Human is irrational in absolute majority.

To consider this assumption, it is enough to analyze the decision-making mechanisms in both local and global audience. Considering the local audience, it can be stated that a process of decision-making among a lot of people, mostly youth, is characterized by no adequate inherent study, analysis of scenarios on the basis of potential changes, current modifications of the solution on the basis of sequence of unpredictable events (Danaher, 2017; Benedikter, 2017). Here we can mention the case of Ukrainian society, which was studied within the concept of the taste of life considered as a degree of an individual's satisfaction from living, functioning and carrying out his own activity in society in accordance with its economic rules and orders (Hurnyak \& Kordonska, 2018 a).

We see the main reason for such consequence in a decrease of the level of math at school and university. An even greater threat for future generation is an attempt to dissolve physics from the school curriculum, which in general makes it impossible for a young person to form an adequate understanding of the laws of universe. Apart from this, the academic environment lobbies the established traditional approaches and refuses unconventional solutions without going into the details. A fresh look sometimes penetrates, but more often - fades away. Evidently it must stay somewhere in this "desert of the new ideas," that is, virtuality.

According to the presented assumptions, we are unable to realize rational projects in traditional way in the irrational world. Thereby we have to create a research environment with such pillars as self-realization and self-supporting. It should be a world built on the basis of our limitations, our choice, our understanding of rationality. Obviously, this would be relatively rational world, but it corresponds to our perceptions. It is obvious that it will lose its status in the future, but in the short term it seems possible. 
An example: What is the financial pyramid? - It is the actual formation of the financial illusion in virtuality. What makes possible to form temporary effective pyramids? It is virtuality or some type of AR. What can make it impossible? The modern audit standards, approaches, authorities and especially the current American experience can resolve this issue. But this solution is not long-lasting and involves new tools for future manipulation. Artificial intelligence can become an unexpected player in this field, which will modernize the system on an ongoing basis and remove the field for manipulation. What about a virtual accountant and a virtual auditor? The virtuality can ensure a possibility of combining these two posts without compromising strategic development, identifying the threshold of materiality, understanding the prospects of business and industry. That is, someone who visits your company virtually, but remains absolutely resistant to a friendship lunch, a joint rest, a fear of losing a powerful and promising client (as in the case of relationship between Enron and Arthur Anderson companies recently) or an impolite in an effort to identify all introduced cost manipulations. Apart from this, the virtuality can also become an effective tool in the mechanism of overcoming corruption or institutional interaction (Hurnyak \& Kordonska, 2018a,b; 2019).

Assumption no. 3. A virtuality is a threat and an opportunity to the human.

What will we do when such artificial rationality will be changed into artificial irrationality? Pulling towards short messages, quick decisions, quick dating and braking, minimal responsibility for deeds and words? This is partly a result of penetration of the virtual technologies. Simultaneously, the same rational virtuality, already overpowered by such solutions, becomes eager to change this, and it is striving for other more complex ways and options. The virtuality becomes self-taught and takes over the person's ability to self-education. Is it worth being afraid that virtuality is getting closer to a real rational person and more capable for self-organization and self-control, that is, even "better" than a human?

Could a human create a perfect virtuality, even if he is not optimal, not rational, selfish, without deeply thinking ability or even hanging out from time to time and without possibility to analyze properly the consequences of its actions? Will such created virtuality be a threat to human? - Of course, Yes.

\section{Interaction between physical and virtual reality}

\section{Payoff matrix of Nash equilibrium}

Let's assume that physical reality will cooperate or neglect the cooperation with virtual / augmented reality. A model can be introduced by payoff matrix of Nash equilibrium (Table 
1). According to the game theory, Nash equilibrium is a solution concept of a non-cooperative game involving two or more players in which each player is assumed to know the equilibrium strategies of the other players, and no player has anything to gain by changing only its own strategy. In terms of game theory, if each player has chosen a strategy, and no player can benefit by changing strategies while the other players keep theirs unchanged, then the current set of strategy choices and their corresponding payoffs constitutes Nash equilibrium (Varian, 2010).

Let's assume the next distribution of the points in the case-study: 10 points - investment of physical space into the virtual one (based on the method of Internal Rate of Return (IRR)); 10 points - the discounted cash flows based on IRR (covering the physical space investment); 5 points - unrealized possibilities and losses of the real life (negative externalities); 5 points - additional possibilities in physical space coming from using of VR/AR (positive externalities).

Consequently, a model of interaction between physical and virtual reality presents four cases (Table 1). The upper left sell shows the case of interaction containing the initial investment into virtual reality (10 points) and unrealized possibilities of physical reality transferred to the virtuality ( 5 points). So, it constructs 15 points for virtual reality. On the other hand, this case contains covered costs of investment (10 points) plus additional possibilities coming from using new virtual instruments (5 points), which construct 15 points for physical reality in case of cooperation. Then, the upper right cell presents a situation where virtual reality have at least new possibilities coming from physical reality (5 points), while physical reality neglects interaction ( 0 points). If both realities neglect interaction, there is no initial investment and covering cash flows [0;0]. The lower left sell shows initial investment from readiness to cooperate with physical reality (10 points) for virtual reality and lost invested resources for physical one ( -10 points). In the model of interaction between physical and virtual reality, Nash equilibrium can be achieved in the situation of cooperation [15; 15].

Table 1 - A model of interaction between physical and virtual/augmented reality

\begin{tabular}{|l|l|c|c|c|c|}
\cline { 3 - 6 } \multicolumn{2}{c|}{} & \multicolumn{4}{c|}{ PR (physical reality) } \\
\cline { 2 - 7 } \multicolumn{2}{c|}{} & \multicolumn{3}{c|}{ cooperate } & \multicolumn{2}{c|}{ neglect } \\
\hline $\begin{array}{l}\text { VR/AR } \\
\text { (virtual/augmented } \\
\text { reality) }\end{array}$ & cooperate & $\underline{15}$ & $\underline{15}$ & $\underline{5}$ & 0 \\
\cline { 2 - 6 } & neglect & 10 & -10 & 0 & $\underline{0}$ \\
\hline
\end{tabular}

Source: Own elaboration. 
In terms of institutional economics we have to talk about positive and negative externalities. Could we predict some analogy of Pigouvian $\operatorname{tax}^{4}$ or "Still Mill - fishery" negative externality problem solution? (Varian, 2010). Perhaps in these externalities we can't reveal an invincible reason for the inhibitory effect of underestimated wages or the reason for why some geographically favorably located states are lagging behind the rest of the world despite a wide network of IT companies. Surprisingly, countries with a weakly developed sector of virtual business or robotics, as it turned out, are perhaps the most sensitive to the virtual impact, as manipulation of unprepared and inflexible mind becomes so easy. Let's imagine a crowded bus (in the poorest country of Europe), which is completely uncomfortable, with people somehow reading books, listening to music and even solving mathematical problems in their new smartphones. Such simple example shows how vulnerable people are to the impact of information technology, which becomes essential for those living in unattractive reality.

\section{Internalization approach}

Internalization approach, to explore the essence of mutual interpenetration between virtual and physical reality, could be presented in the way of optimization problem:

$$
p_{f} f Q+p_{v}(1-f) Q-c_{v}(p, q,(1-f) Q)-c_{f}(p, q, f Q) \rightarrow \max
$$

where $f$ - share of time spent in real world; $(1-f)$ - share of time spent in virtuality; $c_{v}-$ cost of human virtuality; $c_{f}-$ cost of human physicality; $p$ - quantity of positive virtual externality; $q$ - quantity of negative virtual externality; $Q$ - the overall time of human activity.

As a result of analysis we can get a condition of profit maximum that in short run is the next:

$$
p_{f}-p_{v}+\frac{\partial c_{v}}{\partial f}-\frac{d c_{f}}{\partial f}=0, \quad \frac{\partial c_{v}}{\partial p}=-\frac{\partial c_{f}}{\partial p} ; \frac{\partial c_{v}}{\partial q}=-\frac{\partial c_{f}}{\partial q}
$$

After rewriting an equation [1], it could be received the next optimization problem:

$$
p_{f} f+p_{v}(1-f)-\left(-l_{1} e^{k_{1} f+l_{1}}+l_{2} e^{k_{2} f+l_{2}}\right)^{1-f}-\left(-l_{3} e^{k_{3} f+l_{3}}+l_{4} e^{k_{4} f+l_{4}}\right) f \rightarrow \max
$$

$$
\text { where } l_{1}, l_{2}, l_{3}, l_{4}, k_{1}, k_{2}, k_{3}, k_{4} \text { - some constants. }
$$

\footnotetext{
${ }^{4}$ A Pigouvian tax is liquid waste, or effluent, a fee which is assessed against private individuals or businesses for engaging in activities that create adverse side effects. Adverse side effects are those costs which are not included as a part of the product's market price (Investopedia).
} 
The case no. 1 .

By evaluating separate variables it is possible to find a graphical solution.

Let's assume that:

$$
\operatorname{Profit}(t)=\left(e^{t+1}-e^{2 t+1}\right)^{0,6-t}+\left(e^{t+1}-e^{2 t+1}\right) t
$$

The conditions of $k_{l}=k_{3}=1$ and $k_{2}=k_{4}=2$ are chosen as application of the partial case of the disease dilemma in behavioral economics; " 0,6 " is a share of the overall time of human activity; $t-$ is a share of time for staying in the real world; all indicators $l$ are equal 1 as initial positive expectations of the technology. In these conditions, as we can see in the graph 1, the basic model is not satisfied as $t$ is not greater than " 0 ".

\section{Graph 1 - Absence of solution}

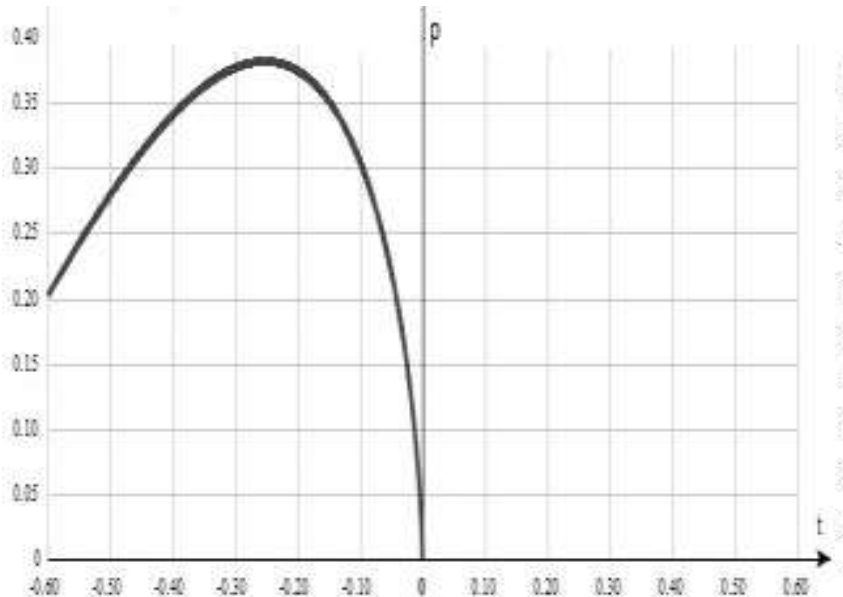

Graph 2 - Traditional approach

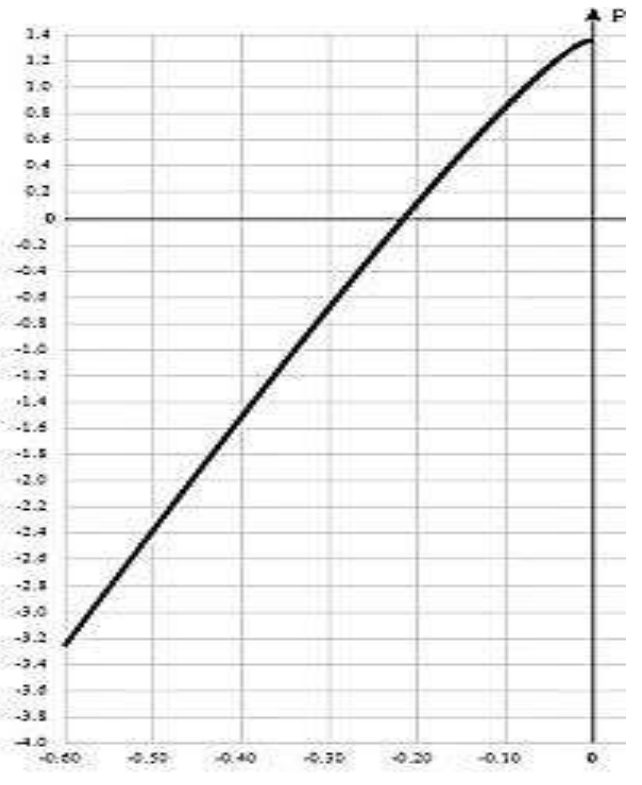

Source: Own elaboration.

The case no. 2.

If we add traditional variables into the profit calculation such as payments (10 and 2 units properly) for the case including or not virtual instruments,

$$
\text { Profit }(t)=10 t+2(0,6-t)+\left(e^{t+1}-e^{2 t+1}\right)^{0,6-t}+\left(e^{t+1}-e^{2 t+1}\right) t
$$

it will not move the position of optimal $t$ to the positive side (Graph 2), because we don't have a solution with a positive $t$. 
Therefore, we have an opportunity to concentrate on the impact of externalities.

Graph 3 - Case no. 1 and case no. 2
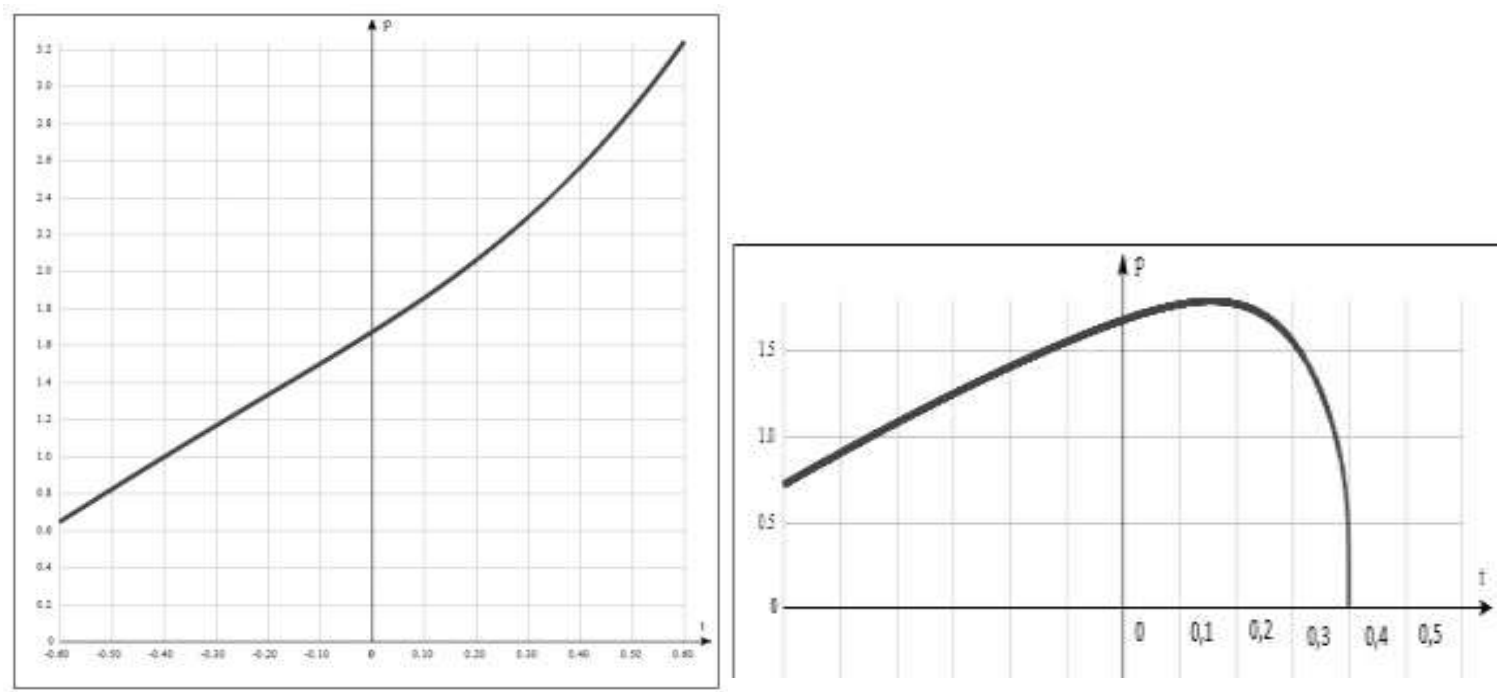

Source: Own elaboration.

In the case no. 1 (Graph 3, case no. 1) we simply assess the initial impact of the virtual technology as " -1 " and then a bad externality impact is expecting two times worth than positive. In case no. 2 this expectations are transforming to the six times worth respectively.

If we rewrite initial equation into:

$$
\operatorname{Profit}(t)=\left(e^{t+1}-e^{6 t-1}\right)^{0,6-t}+\left(e^{t+1}-e^{6 t-1}\right) t
$$

the optimal coexistence of the physical and virtual provided in such model is achieved in the case of $t \approx 0,15$.

Such a gradual transition to the perception of virtual technology with the expectations rising rapidly from its negative externalities in the future can be explained by the comparison of a substantially negatively motivated individual with the initial estimate " -1 ," and therefore the current comparative advantage of the application of technology right now. Other words, we can lose our vision by watching a lot of movies, knowing that it's bad, but all these negative externalities will happen with us in the future. Such arguments in such model could be acceptable. 


\section{Graphical visualization of the solution}

Let's imagine the interaction of the virtual and real worlds (Figure 2). "A" - is the area of no virtuality; "B" - is the area of no physical reality. For the case of the figure "SR" - a solution is the area of "xAx". For the case of the figure "SV" - a solution is the area of "xxAxx" (as we have to include the influence of all previous externalities on all possible levels). Even in the case of intersection area which combine Virtual and Physical areas (figure "S"), there is no certainty that it is exactly the best solution to our problem. In other words, artificially created centrifugal stresses have to push virtuality into reality or compress an over-developed virtuality. That is why, the solutions will be situated in the points of tangency to the ellipse. In this case we can find some analogies with budget lines and indifferent curves used in Microeconomics.

Figure 2 - Graphical solution of interaction between the virtual and physical worlds

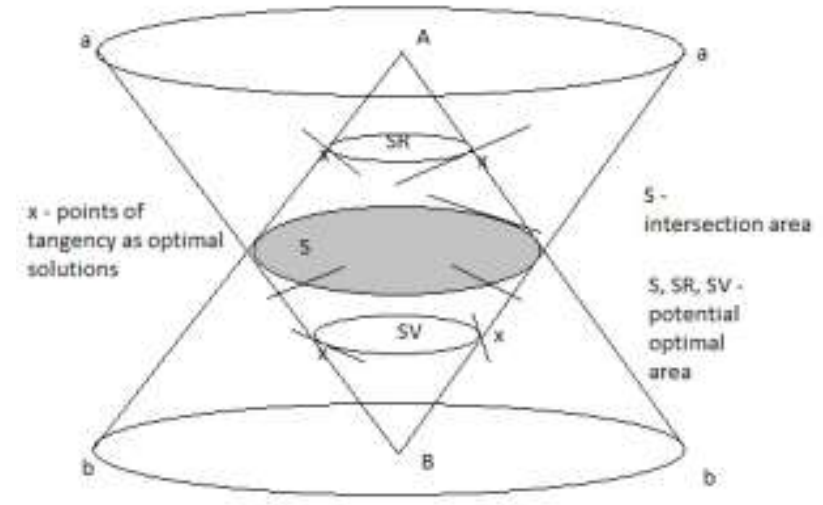

Source: Own elaboration.

Given the loss of initial connectivity between the physical and virtual world, finding a common one, and thus the optimal solution becomes a rather complicated task. Let's emphasize that the identified cones of virtuality and real world are always in motion, and that would have to count and predict the trajectory of the motion of each cone. It is not easy to find a solution for the original conditional statics (Figure 3). 
Figure 3 - Graphical solution of interaction between the virtual and physical worlds (cones in motion)

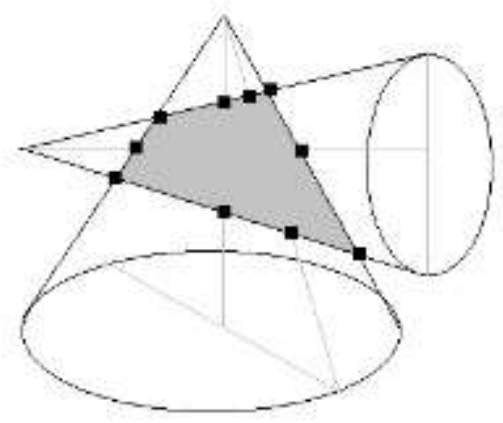

Notes: If the "parent" world refuses its status as an inventor and does not monitor the livelihoods of its invention, the solution to this problem becomes very complicated.

Source: Own elaboration.

In the area "A" and "B" decision is only in the point A and the point B (Figure 4). Interaction of the virtual reality, that pushes the user into cooperation with the physical one, the solution are the points located on the highest ellipse that touches the budget curves determined on the basis of compensation in virtual and real spaces (Figure 4).

Figure 4 - Interactions between virtual reality and physical reality

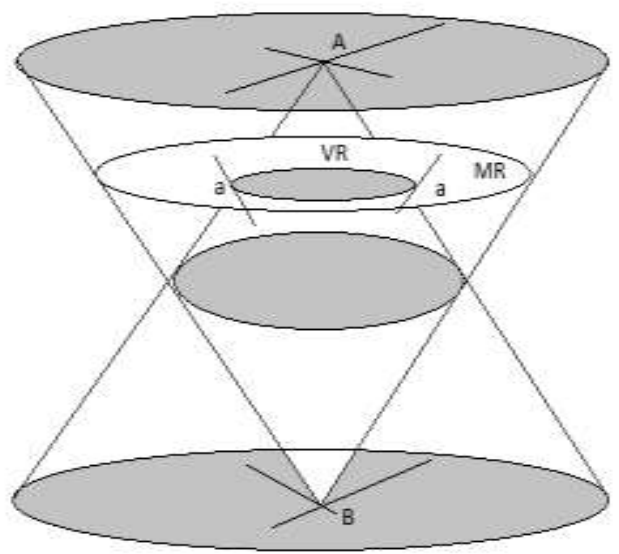

Source: Own elaboration.

\section{Cost function and the city's economy}

As we could not predict what is direct influence or direct aim - all costs are identified as externalities in the form of indicative function of time. Since a person is irrational and its predictions do not correspond to the exponential nature of information technology, we consider the cost function as a function of positive and negative externalities, other words, unexpected 
positive and negative effects. Under such conditions, the role of physical capital is minimized, and human capital is represented as the exponential function of time spent by working with and without the use of virtual technologies.

What $f$ will maximize our profit in this case? Or, other words, how time could be optimally redistributed by different $Q$ and different approaches to utility valuation? Partially, as was shown, we can answer these questions.

Let's assume that $c_{f}$ is approximately equal to the housing costs, then recalling the most famous equation of the city's economy (a model of optimal city size):

$$
\text { wage }+ \text { aminities }- \text { housing costs }=0 .[6]
$$

Rewriting this condition, we could get a dynamics of current changes:

$$
\begin{array}{r}
\text { wage } \downarrow+\text { traditional aminities } \downarrow+\text { virtual aminities } \uparrow \\
\text {-traditional housing cost } \downarrow+\text { virtuality costs } \uparrow=0 \text { [7] }
\end{array}
$$

We understand that the presence of virtual reality destroys this underestimation of the leverage for individuals and forces them to build new pillars of the city's economy in another way. In fact, an equation no. 6 has to be rewritten in a form of equation no. 7 with the next optimization analysis.

If we will try to rebuild a Richardson (1972) model of optimal city size (regarding the influence of emigrants), the result becomes threatened in view of the permissible minimization of the infrastructure and the withdrawal of a part of the inhabitants from the real functioning of the city concerning profit maximization. Maybe in such conditions it becomes necessary to look for entirely new approaches and new assessments to the concept and understanding of equilibrium in human life or to be more focused on the life of the city.

According to the traditional approach we can increase tolerance to the growth of city population by moving to the right marginal cost and marginal benefit point of intersection (Graph 4). In the Graph 4 are presented: MCF, MBF - marginal costs and benefits, $\mathrm{MC}(\mathrm{F}+\mathrm{V})$, MB $(F+V)$ - the same variables in the case of coexistence of the virtuality and real world. Perhaps this is one of the main reasons for transforming our cities into a so-called "virtual zones." 
Graph 4 - Point of equilibrium in the life of the city

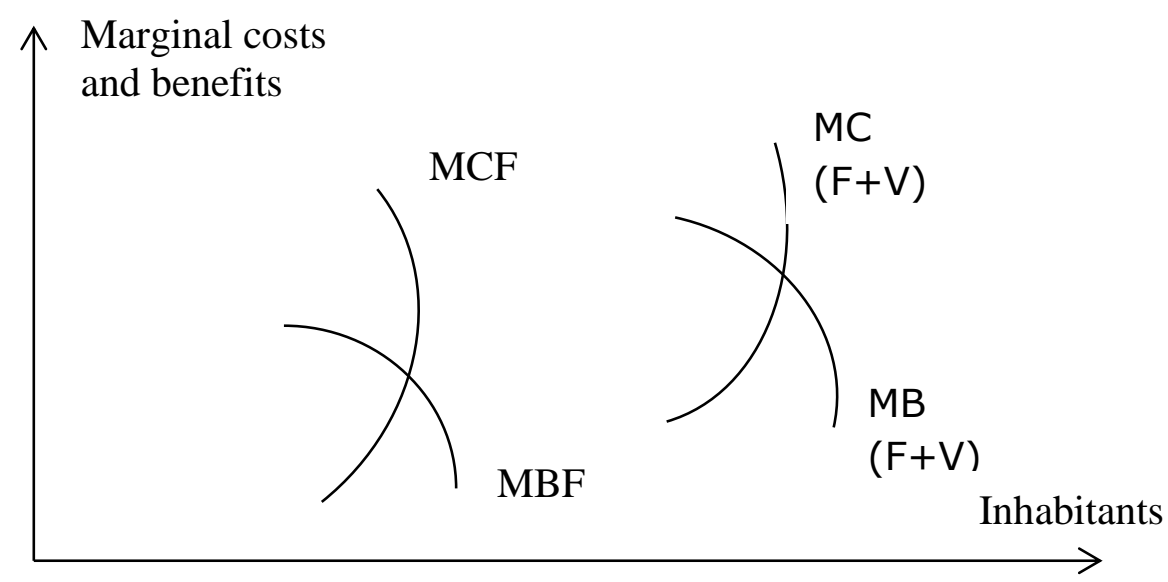

Source: Own elaboration.

\section{Discussion and conclusions}

A new stage of history has just started. The question arises: who is a human today and what is the level of intelligence on the Earth? Human has developed virtuality as a tool for more comfortable life, but will a smart virtuality try to develop a human? Could a human refuse this idea as a result of his inability due to irrationality? Maybe it would be even too late for such reflection?

Nowadays any scientific analysis and any scientific discussion should include human capital closely tangent to the virtuality. Based on payoff matrix we demonstrated the need of cooperation between physical and virtual reality to achieve Nash equilibrium. We made a graphical visualization to show the interaction between the virtual and real worlds by using cones movement approach. Furthermore, we focused on penetration of the physical / virtual space by each other in the way of optimization problem by using internalization approach and graphical solution.

Since a person is irrational, its predictions do not correspond to the real nature of things. The still functioning exponential nature of information technology, which coexists with the linearity of our educational perception, forces to predict this inability by constructing dependence of costs as function of positive and negative exponential externalities. The proposed cost-based approach as an exponential function of positive and negative externalities allows finding the optimal distribution of the time staying in the virtual and physical space. Other words, we are looking for some ratio of coexistence between these realities. The same 
goes for the cost of virtual amenities or calculation of labor productivity in the city's economy. Under such conditions, the role of physical capital is minimized, and the human capital is represented as a function of time spent by working with or without the use of virtual technologies. So, in our research we developed an equation of the city's economy by taking into account variables representing virtual reality and try to rebuild a model of optimal city size.

Considering current times we believe, that the task of virtual product, with exception of a number of marginal cases, should be non-intrusive pushing of a man into the real world, a kind of propagation of the cult of the physical world. Virtuality should become an ally of the real world in solving real problems of the state, city and community.

\section{References}

Benedikter, R. (2017). Homo deus? Das Zusammenwachsen von Mensch und Maschine. Analysen \& Argumente, 270.

Bhalavat, K. (2018). Augmented Reality to Teleport you into Virtual Worlds. Retrieved from https://www.linkedin.com/pulse/augmented-reality-teleport-you-virtual-worlds-keyurbhalavat (Accessed 9 June 2018).

Blissing, B. (2016). Driving in Virtual Reality Investigations in Effects of Latency and Level of Virtuality, LiU-Tryck: Linköping University, Sweden.

Carvalho, G., Kovaleski, J., Carvalho, H., Corrêa, R., Sokulski, C. \& Kolotelo, J. (2018). The Impact of Organizational Innovativeness on Product-oriented innovativeness in Agroindustrial micro and small businesses. International Journal of Innovation, 6(3), 217-231. doi:10.5585/iji.v6i3.312

Danaher, J. (2017). The Reality of Virtual Reality: A Philosophical Analysis, Institute for Ethics and Emerging Technologies. Retrieved from https://ieet.org/index.php/IEET2/more\%20/Danaher20170918?fbclid=IwAR3ZFzTXshqW 9Ko81a8YuF4UIOhp3TuZY2mOTg1ldINUFe2382xly9ms7wI (Accessed 18 September 2017).

Google Books Ngram Viewer. Available at: https://books.google.com/ngrams.

Hurnyak, I. \& Kordonska, A. (2018a). "Taste of Life" as a Mechanism of Corruption Overcoming. Comparative Economic Research. Central and Eastern Europe, 21(2): 69-80. doi:10.2478/cer-2018-0012

Hurnyak, I. \& Kordonska, A. (2018b). Efficient Use of Common Resources in Conditions of Sustainable Development. Torun International Studies, 1(11): 75-87. doi:10.12775/TIS.2018.007

Hurnyak, I. \& Kordonska, A. (2019). Analysis of Institutions Interaction in Ukrainian Economy by Using Game Theory Models. Przeglad Wschodnioeuropejski, X/1: 139-151. 
Kagan, J. (2018). Pigovian Tax, Investopedia. Retrieved from https://www.investopedia.com/terms/p/pigoviantax.asp (Accessed 2 May 2018).

Kaku, M. (2008). Physics of the Future: How Science Will Shape Human Destiny And Our Daily Lives by the Year 2100. Doubleday, New York.

Kim, M. (2015). The Good and the Bad of Escaping to Virtual Reality. The Atlantic. Retrieved from https://www.theatlantic.com/health/archive/2015/02/the-good-and-the-badof-escaping-to-virtual-reality/385134/ (Accessed 18 February 2015).

Kurzweil, R. (2003). Foreword to Virtual Humans. Kurzweil Accelerating Intelligence. Retrieved from https://www.kurzweilai.net/foreword-to-virtual-humans (Accessed 20 October 2003).

Marr, B. (2019). 5 Important Augmented and Virtual Reality Trends for 2019 Everyone Should Read. Forbes. Retrieved from https://www.forbes.com/sites/bernardmarr/2019/01/14/5-important-augmented-and-virtualreality-trends-for-2019-everyone-should-read/\#5cb2953c22e7 (Accessed 14 January 2019).

Pham, Q. \& Huynh, M. (2018). Learning achievement and knowledge transfer: the impact factor of e-learning system at Bach Khoa University, Vietnam. International Journal of Innovation, 6(3): 194-206. doi:10.5585/iji.v6i2.235

Richardson, H.W. (1972). Optimality City Size, Systems of Cities and Urban Policy: A Sceptic's View. Urban Studies, 9(1): 29-48. doi:10.1080/00420987220080021

Schaller, R. (1997). Moore's law: past, present and future. IEEE Spectrum, 34(6): 52-59. doi:10.1109/6.591665

The Guardian (2011). At war with World of Warcraft: an addict tells his story. Retrieved from https://www.theguardian.com/technology/2011/aug/29/world-of-warcraft-video-gameaddict (Accessed 29 August 2011).

Varian, H.R. (2010). Intermediate Microeconomics. A Modern Approach, W.W. Norton \& Company, New York.

Zion Market Research (2019). Global Augmented and Virtual Reality Market Will Reach USD 814.7 Billion By 2025. Retrieved from https://www.globenewswire.com/newsrelease/2019/02/21/1739121/0/en/Global-Augmented-and-Virtual-Reality-Market-WillReach-USD-814-7-Billion-By-2025-Zion-Market-Research.html (Accessed 21 February 2019). 